\title{
INFLUENCE OF SOAKING 30\% AND 50\% BAKING SODA (sodium bicarbonate) SOLUTION FOR 5, 10, DAN 15 DAYS TOWARDS TOOTH DICOLORISATION
}

\author{
Diyah Fatmasari', Ratnawati Hendari², Irma HY Siregar ${ }^{3}$
}

\begin{abstract}
One cause of teeth apperance disruption is teeth discoloritation. Tooth disclorisation caused by intrinsic, extrincic and aged related factor. Several ways to change yellow teeth become white teeth. Baking soda is one of such material which can whiten teeth. Recent research aims to find $30 \%$ and $50 \%$ baking soda solution effectiveness towards teeth discolorisation.

Experimental with pre-post group design was used as research design. Baking soda solution was made with two different concentration (30 and 50\%), then teeth was measured the white level with shade guide. Samples then soaked in baking soda solution for 5, 10, and 15 days. Every 5 days the teeth was re-measured the white level until 15 days.

Research results shown baking soda solution $50 \%$ is more effective to whiten teeth than baking soda solution $30 \%$. Further research about baking soda for whiten teeth is needed.
\end{abstract}

Key words : Baking Soda, soaked, tooth discoloritation

$\overline{\text { 1,2,3) Dosen Jurusan Keperawatan Gigi Poltekkes Kemenkes Semarang }}$

\section{PENDAHULUAN}

\section{Menurut WHO kesehatan rongga mulut saling berhubungan dengan} kesehatan umum dan kesadaran untuk menjaga kesehatan rongga mulut berperan penting dalam menentukan kesehatan rongga mulut seorang individu. Kesehatan gigi merupakan salah satu aspek dari kesehatan secara keseluruhan. Dengan demikian kesehatan gigi juga merupakan hasil dari interaksi antara kondisi fisik, mental dan sosial (Herijulianti dkk, 2002).

Gigi geligi mempunyai peranan penting pada waktu bicara dan juga menentukan wajah seseorang. Selain itu gigi dan mulut berfungsi sebagai estetik dan kecantikan, sehingga banyak yang beranggapan bahwa gigi dan mulut adalah bagian integral kesehatan umum serta estetik gigi yang merupakan hal yang tak ternilai (Howwink et al, 1993). Gigi yang sehat akan meningkatkan rasa percaya diri seseorang. Jika penampilan gigi seseorang kurang rapi, kotor, bewarna kusam atau berwarna coklat kehitam-hitaman maka akan menurunkan rasa percaya diri seseorang (Howwink, 1993).

Salah satu penyebab terganggunya penampilan gigi adalah perubahan warna gigi (stain). Perubahan warna gigi adalah kelainan warna gigi rata-rata yang dapat dilihat secara klinis (Howwink, 1993). Penyebab perubahan pewarnaan gigi (stain) ada faktor ekstrinsik, intrinsik dan pengaruh akibat usia.

Faktor ekstrinsik terjadi pada permukaan luar gigi dan biasanya disebabkan kebiasaan minum-minuman berwarna yang berkepanjangan seperti teh, kopi, atau sirup yang dapat menyebabkan perubahan warna dari coklat sampai hitam. Perubahan warna gigi pada perokok akibat pemakaian tembakau baik dihisap atau dikunyah dapat menyebabkan tertumpuknya tar pada permukaan gigi. Faktor intrinsik terjadi karena penggunaan obat antibiotik tetracyline pada setengah masa kehamilan. Faktor akibat pengaruh usia karena menipisnya permukaan email 
sehingga mengakibatkan warna kuning dari dentin di bawahnya menjadi lebih terlihat (Rhamadan, 2010).

Di masyarakat sekarang tengah marak perawatan untuk memutihkan gigi dengan teknik bleaching. Teknik bleaching adalah suatu cara pemulihan gigi yang berubah warna, sampai mendekati warna gigi asli dengan proses perbaikan secara kimiawi (Tarigan, 1994). Teknik bleaching merupakan teknik pemutihan gigi dengan menggunakan bahan kimia yang bersifat asam, bahan bleaching yang masuk melalui tubuli dentin yang terbuka menuju ke jaringan periondontal mengakibatkan peradangan pada jaringan periodontal (Halim, 2010).

Sebagian masyarakat belum mengetahui cara memutihkan gigi dengan menggunakan cara dan bahan yang sederhana. Baking soda (sodium bicarbonate) bisa digunakan sebagai alternatif umtuk memutihkan gigi,selain mudah ditemui di masyarakat, baking soda juga relatif lebih mudah digunakan. Kelebihan baking soda dibandingkan dengan larutan kimia adalah baking soda tidak bersifat iritan dan abrasif. Baking soda juga bisa sebagai antibakterial (Schuurs, 2013).

Untuk alasan tersebut diatas,maka peneliti ingin melakukan penelitian dengan memanfaatkan larutan baking soda sebagai alternatif untuk memutihkan gigi.

\section{METODE PENELITIAN}

Desain penelitian adalah penelitian eksperimen dengan rancangan penelitian pre-post group design. Cara pengukuran dengan melakukan satu kali pengukuran sebelum adanya perlakuan (pre-test) dan sesudah adanya perlakuan dilakukan pengukuran lagi (post-test) (Nasir dkk, 2011). Sampel penelitian ini adalah 4 gigi anterior permanen non vital.

Dengan menggunakan rumus Federer :

$$
\begin{aligned}
& (k-1)(n-1) \geq 15 \\
& (6-1)(n-1) \geq 15 \\
& 5 .(n-1) \geq 15 \\
& n=4
\end{aligned}
$$

Variabel pengaruh dalam penelitian ini yaitu baking soda konsentrasi 30\% dan $50 \%$. Variabel terpengaruh dalam penelitian ini yaitu perubahan warna gigi non vital. Variabel terkendali dalam penelitian adalah gigi anterior permanen yang telah dicabut dan bebas dari kalkulus dengan perwarnaan gigi A3.5,A3,C2 (elemen gigi 31 1, 31 2, 32, 41, 32 1, 32 2, 21, 41) ; waktu perendaman 5, 10, 15 hari (20 menit setiap harinya); volume larutan; cahaya; anatomi; suhu ruangan.

Larutan dengan konsentrasi 30\% menggunakan aquades sebanyak $100 \mathrm{ml}$, ditambah dengan baking soda seberat $30 \mathrm{gr}$ dilarutkan dalam gelas ukur diaduk menggunakan sendok sampai rata, lalu tuangkan larutan kedalam pot kecil yang sudah terisi gigi non vital, masukkan larutan sampai gigi terendam sepenuhnya.

Larutan dengan konsentrasi 50\% menggunakan aquades sebanyak $100 \mathrm{ml}$, ditambah dengan baking soda seberat $50 \mathrm{gr}$ dilarutkan dalam gelas ukur diaduk menggunakan sendok sampai rata, lalu tuangkan larutan kedalam pot kecil yang sudah terisi gigi non vital, masukkan larutan sampai gigi terendam sepenuhnya.

Kode warna gigi dan skor setiap gigi pada shade guide adalah sebagai berikut:

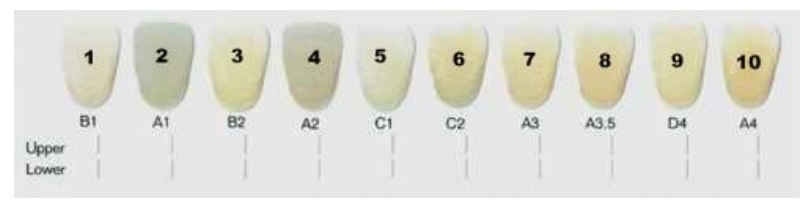

Adapun prosedur penelitian adalah $\mathrm{sbb}$ :

1. Pembuatan Larutan Baking Soda dengan konsentrasi $30 \%$ dan $50 \%$

a. Siapkan bahan penelitian (baking soda dan aquades)

b. Siapkan instrument penelitian (baker glaas,gelas ukur, sendok makan, timbangan manual, stopwatch, 8 pot kecil yang sudah diberi label)

c. Buat larutan baking soda dengan konsentrasi 30\% dan 50\% 
d. Letakkan larutan yang sudah dibuat pada 8 pot kecil yang sudah diberi label.

e. Letakkan satu gigi pada masingmasing pot yang sudah diberi label.

f. Gunakan stopwatch untuk mengukur waktu.

2. Perhitungan Derajat Keputihan

Perendaman dilakukan dengan membagi 2 kelompok, yaitu konsentrasi 30\% dan $50 \%$. Perendaman itu dilakukan selama 20 menit setiap hari selama 5, 10, dan 15 hari. Sesudah perendaman sampel disikat untuk menghilangkan sisa larutan baking soda yang masih menempel. Perhitungan dilakukan secara manual dengan menggunakan shade guide dengan melakukan pengukuran dan pemotretan sebelum dan sesudah dilakukan penelitian, supaya dapat dibandingkan perubahan antara sebelum dan sesudah penelitian. Setiap 5 hari sekali sampai dengan 15 hari, perubahan warna diukur menggunakan shade guide. Pengukuran dengan shade guide yaitu dangan cara menyesuaikan warna gigi dengan warna shade guide yang sesuai. Perbedaan 1 point atau lebih akan membuktikan keberhasilan penelitian.

Data yang diperoleh dari hasil pengamatan dianalisa untuk mengetahui efektivitas larutan baking soda yang dimanfaatkan untuk memutihkan gigi. Analisa data yang digunakan dapat diketahui dengan metode kuantitatif dengan menggunakan uji independent $t$ test.

\section{HASIL DAN PEMBAHASAN}

Berdasarkan hasil penelitian yang dilakukan di laboratorium IPA SMP N 21 Semarang pada tanggal 13-27 Mei 2014 dengan judul "efektifitas larutan baking soda (sodium bicarbonate) konsentrasi 30\% dan $50 \%$ dengan lama perendaman selama 5, 10, dan 15 hari terhadap perubahan warna gigi non vital diperoleh hasil sebagai berikut :

Tabel 1. Perubahan Warna Gigi Non Vital Sebelum dan Sesudah Perendaman Baking Soda Konsentrasi 30\% Selama 5, 10 dan 15 hari

\begin{tabular}{|c|c|c|c|c|c|c|c|c|}
\hline \multirow{3}{*}{ Elemen Gigi } & \multicolumn{2}{|c|}{ Sebelum } & \multicolumn{6}{|c|}{ Sesudah } \\
\hline & \multirow{2}{*}{\multicolumn{2}{|c|}{ Kode skor }} & \multicolumn{2}{|c|}{5 hari } & \multicolumn{2}{|c|}{10 hari } & \multicolumn{2}{|c|}{15 hari } \\
\hline & & & kode & skor & kode & $\mathrm{kol}$ & kode & skor \\
\hline $31_{1}$ & $\mathrm{~A}_{4}$ & 10 & $\mathrm{~A} 3,5$ & 8 & $\mathrm{~A} 3,5$ & 8 & $\mathrm{C}_{2}$ & 6 \\
\hline 312 & $\mathrm{~A}_{4}$ & 10 & $\mathrm{~A} 3,5$ & 8 & $\mathrm{C}_{2}$ & 6 & $\mathrm{C}_{2}$ & 6 \\
\hline 32 & $\mathrm{~A} 3,5$ & 8 & $\mathrm{~A} 3,5$ & 8 & $\mathrm{C}_{2}$ & 6 & $\mathrm{C}_{2}$ & 6 \\
\hline 41 & $\mathrm{C}_{2}$ & 6 & $\mathrm{C}_{2}$ & 6 & $\mathrm{~A}_{2}$ & 4 & $\mathrm{~A}_{2}$ & 4 \\
\hline $\begin{array}{l}\text { Rata-rata } \\
\text { Perubahan } \\
\text { warna }\end{array}$ & & 8,5 & & 7,5 & & 6 & & 5,5 \\
\hline
\end{tabular}

Tabel 1 menunjukkan rata-rata skor perubahan warna gigi sebelum perendaman dengan konsentrasi $30 \%$ adalah 8,5 sesudah perendaman selama 5 hari 7,5 sesudah perendaman selama 10 hari 6 sesudah perendaman selama 15 hari 5,5. 
Tabel 2. Perubahan Warna Gigi Non Vital Sebelum dan Sesudah Perendaman Baking Soda Konsentrasi 50\% Selama 5, 10 dan 15 hari

\begin{tabular}{|c|c|c|c|c|c|c|c|c|}
\hline \multirow{3}{*}{ Elemen Gigi } & \multicolumn{2}{|c|}{ Sebelum } & \multicolumn{6}{|c|}{ Sesudah } \\
\hline & & & \multicolumn{2}{|c|}{5 hari } & \multicolumn{2}{|c|}{10 hari } & \multicolumn{2}{|c|}{15 hari } \\
\hline & kode & skor & kode & skor & kode & skor & kode & skor \\
\hline 321 & $\mathrm{~A}_{4}$ & 10 & $\mathrm{~A}_{4}$ & 10 & $\mathrm{~A}_{3,5}$ & 8 & $\mathrm{C}_{2}$ & 6 \\
\hline 322 & $\mathrm{~A} 4$ & 10 & $\mathrm{~A} 4$ & 10 & $\mathrm{~A} 3,5$ & 8 & $\mathrm{~A}_{3,5}$ & 8 \\
\hline 21 & $\mathrm{~A}_{4}$ & 10 & $A_{3,5}$ & 8 & $\mathrm{C}_{2}$ & 6 & $\mathrm{~A}_{2}$ & 4 \\
\hline 41 & $\mathrm{~A} 3,5$ & 8 & $\mathrm{C}_{2}$ & 6 & $\mathrm{~A}_{2}$ & 4 & $\mathrm{~B}_{2}$ & 3 \\
\hline $\begin{array}{l}\text { Rata-rata } \\
\text { perubahan } \\
\text { warna }\end{array}$ & & 9,5 & & 8,5 & & 6,5 & & 5,25 \\
\hline
\end{tabular}

Tabel 2 menunjukkan rata-rata skor perubahan warna gigi sebelum perendaman dengan konsentrasi $50 \%$ adalah 9,5 sesudah perendaman selama 5 hari 8,5, sesudah perendaman selama 10 hari 6,5, setelah perendaman selama 15 hari 5,25.

Tabel 3. Rata-rata Perubahan Warna Gigi

Non Vital Pada Perendaman Baking Soda $30 \%$ dan 50\% Selama 5, 10 dan 15 hari

\begin{tabular}{|c|c|c|c|c|c|c|}
\hline \multirow{3}{*}{$\begin{array}{l}\text { Konsentra } \\
\text { si }\end{array}$} & \multicolumn{5}{|c|}{ Skor } & \multirow{2}{*}{$\begin{array}{c}\text { Independe } \\
n t \\
t \text { test }\end{array}$} \\
\hline & $\begin{array}{c}\text { Sebelu } \\
\text { m }\end{array}$ & & $\begin{array}{c}\text { Sesuda } \\
\mathrm{h}\end{array}$ & & $\begin{array}{c}\text { Selisi } \\
\mathrm{h}\end{array}$ & \\
\hline & & $\begin{array}{c}5 \\
\text { har } \\
\text { i }\end{array}$ & 10 hari & $\begin{array}{c}15 \\
\text { har } \\
\mathrm{i}\end{array}$ & & \\
\hline $30 \%$ & 8,5 & 7,5 & 6 & 5,5 & 3 & \\
\hline $50 \%$ & 9,5 & 8,5 & 6,5 & $\begin{array}{c}5,2 \\
5\end{array}$ & 4,25 & $0,02^{*}$ \\
\hline
\end{tabular}

Berdasarkan Tabel 3 diketahui hasil penelitian menunjukkan rata-rata perubahan pewarnaan gigi konsentrasi 30\% adalah 3, sedangkan konsentrasi $50 \%$ terjadi selisih warna 4,25. Independent $t$ tset menunjukkan signifikansi yang berarti adanya perbedaan perubahan warna setelah perendaman baking soda 30 dan $50 \%$. Sesudah perendaman baking soda $50 \%$ terjadi perubahan warna gigi lebih tinggi (gigi menunjukkan warna lebih putih).

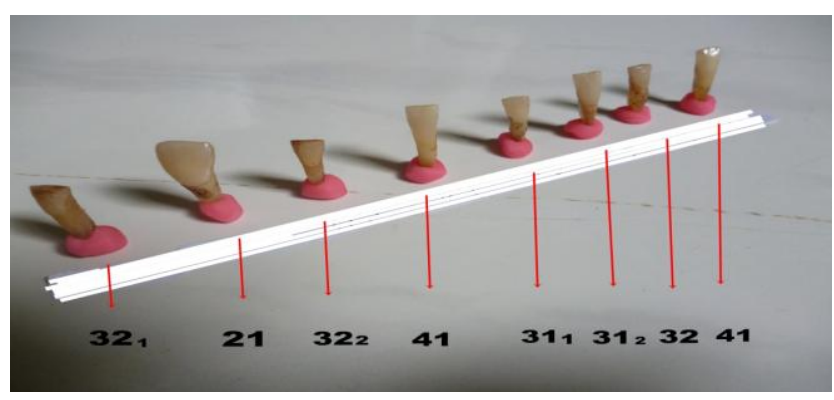

Gambar 1. Warna gigi sebelum perendaman sodium bikarbonat

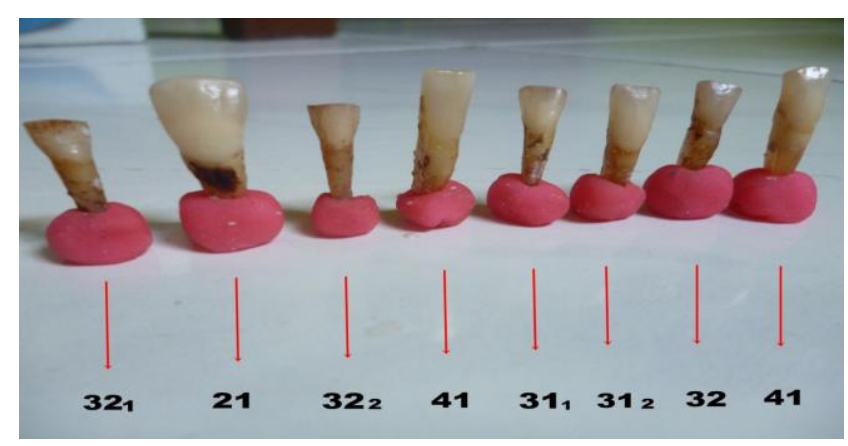

Gambar 2. Warna gigi setelah perendaman sodium bikarbonat

Berdasarkan hasil penelitian yang dilakukan pada tanggal 13-27 Mei 2014 di Laboratorium IPA SMP N 21 Semarang tentang keefektifan baking soda konsentrasi $30 \%$ dan $50 \%$ terhadap pewarnaan gigi non vital, tetapi karena ada kendala waktu observasi dilakukan dirumah peneliti, dari hasil obeservasi terlihat perubahan warna yang semula kuning menjadi agak putih.

Sesudah dilakukan perlakuan yaitu dengan merendam gigi non vital dengan konsentrasi 30\% dan 50\% selama 20 menit setiap hari dengan lama waktu 5, 10, dan 15 hari, gigi non vital menjadi agak putih yang semula berwarna kekuningan. Hal ini disebabkan oleh adanya reaksi oksidasi oleh baking soda dan oksigen. Baking soda 
berdifusi menembus enamel dan dentin, hal itu terjadi karena molekul rendah natrium bikarbonat ditentukan oleh jumlah pemutih dibandingkan dengan jumlah kerugian. Selama proses pemutihan senyawa cincin karbon dibuka dan dikonversi menjadi ikatan rantai unsur yang lebih ringan. Senyawa karbon ikatan rangkap yang ada diubah menjadi gugus hidroksil (Johar, 2011).

Hasil penelitian menunjukkan ratarata pewarnaan gigi sesudah dilakukan perendaman dengan konsentrasi $30 \%$ adalah 8,5 dan rata-rata perubahan warna gigi sesudah perendaman selama 5 hari adalah 7,5, setelah 10 hari adalah 6 , sesudah 15 hari adalah 5,5. Terdapat selisih rata-rata perubahan pewarnaan gigi 3. Hal ini membuktikan bahwa adanya penurunan score mencapai 3 tingkat yang berarti terjadinya perubahan warna gigi menjadi putih. Sedangkan rata-rata pewarnaan gigi sesudah dilakukan penelitian dengan konsentrasi $50 \%$ adalah 9,5, setelah 5 hari adalah 8,5 , setelah 10 hari adalah 6,5 , setelah 15 hari 5,25. Terdapat selisih rata-rata perubahan pewarnaan gigi adalah 4,25.

Hal ini membuktikan bahwa adanya penurunan skor mencapai 4 tingkat yang berarti terjadinya perubahan pewarnaan gigi menjadi putih. Sehingga dapat disimpulkan bahwa baking soda konsentrasi $50 \%$ lebih efektif digunakan sebagai alternatif bahan untuk memutihkan gigi karena semakin besar konsentrasi pereaksi atau semakin pekat pereaksinya maka semakin cepat reaksi berlangsung. Larutan dengan konsentrasi $50 \%$ yang lebih pekat karena pada larutan tersebut terdapat $50 \%$ zat terlarut yang menyebabkan reaksi lebih cepat berlangsung atau lajunya lebih cepat (Munyati, 2007).

\section{KESIMPULAN}

1. Larutan baking soda konsentrasi 50\% lebih efektif digunakan untuk bahan alternatif memutihkan gigi dari pada konsentrasi $30 \%$.
2. Warna gigi rata-rata sebelum perendaman dengan konsentrasi $30 \%$ adalah skor 8,5 , sesudah 5 hari skor 7,5, sesudah 10 hari skor 6 dan sesudah 15 hari skor 5,5.

3. Warna gigi rata-rata sebelum perendaman dengan konsentrasi 50\% adalah skor 9,5, sesudah 5 hari skor 8,5 , sesudah 10 hari skor 6,5 dan sesudah 15 hari skor 5,25.

4. Rata-rata selisih perubahan warna gigi sebelum dan sesudah dilakukan penelitian dengan konsentrasi $30 \%$ adalah 3 dan rata-rata selisih perubahan warna gigi sebelum dan sesudah dilakukan penelitian dengan konsentrasi $50 \%$ adalah 4,25 .

\section{DAFTAR PUSTAKA}

Halim, H.S., 2010, Perawatan Diskolorasi Gigi Dengan Teknik Bleaching, Universitas Trisakti, Jakarta

Herijulianti, E., Indriani, T.S., Artini, S., 2002, Pendidikan Kesehatan Gigi, Buku Kedokteran, EGC, Jakarta

Howwink, Cramwikel, A.B., Korig, K.G.H, Tan, H.,1993, Ilmu Kedokteran Gigi Pencegahan, Universitas Gadjah Mada Press, Yogyakarta

Johar, K., 2011, Fundamental of laser dentistry, Jaypee Brother Medical Published

Munyati, S., 2007, Konsentrasi, http:// www.kimia.upi.edu/utama/b ahanajar/ kuliah_web. 31 Mei 2014

Nasir, ABD., Muhith, ABD., Ideputri, M.E., 2011, Buku Ajar Metodologi Penelitian Kesehatan Konsep Pembuatan Karya Tulis Ilmiah dan Thesis Untuk Mahasiswa Kesehatan, Muha Medika, Yogyakarta

Ramadhan, A.G., 2010, Serba-Serbi Kesehatan Gigi dan Mulut, Bukune, Jakarta 
Schuurs, A.H.B., 2013, Pathology of Hard Dental Tissue

Suryo, S., 1993, Ilmu Kedokteran Gigi Pencegahan, Universitas Gadjah Mada Press Yogyakarta

Tarigan, R., 1994, Perawatan Pulpa Gigi (Endodonti), Widya Medika, Jakarta 